\title{
Management of Basal Stem Rot (Ganoderma Wilt) in Coconut with Effective Bioagents under Field Condition
}

\author{
B. Neeraja $^{1^{*}}$, A. Snehalatharani ${ }^{1}$, H.P. Maheswarappa ${ }^{2}$, G. Ramanandam ${ }^{1}$, \\ N.B.V. Chalapathi Rao ${ }^{1}$ and E. Padma ${ }^{2}$ \\ ${ }^{1}$ Horticulture Research Station, Ambajipeta, (Dr. Y.S.R. Horticultural University), East \\ Godavari dt. Andhra Pradesh-533 214, India \\ ${ }^{2}$ All India Coordinated Research Project on Palms, ICAR-CPCRI, Kasaragod, \\ Kerala-671124, India \\ *Corresponding author
}

\section{A B S T R A C T}

\begin{tabular}{|c|c|}
\hline & Among the various fungal diseases affecting coconut palm, basal stem rot (BSR) or wilt or \\
\hline & $\begin{array}{l}\text { the most destructive especially in the lighter soils of Andhra Pradesh. Keeping in view the } \\
\text { minimal use of fungicides, the present investigation was taken up to develop an }\end{array}$ \\
\hline $\begin{array}{l}\text { Basal stem rot, } \\
\text { Biocontrol agents } \\
\text { and Neem cake }\end{array}$ & $\begin{array}{l}\text { ecofriendly biocontrol management package against the basal stem rot disease by } \\
\text { exploring the efficacy of native biocontrol agents under field conditions. The experiment } \\
\text { was initiated during September } 2014 \text { at P. Gannavaram village of East Godavari District of }\end{array}$ \\
\hline Article Info & $\begin{array}{l}\text { Andhra Pradesh to standardize the dosage, frequency and method of application of } \\
\text { effective biocontrol agents, Trichoderma reesei, Pseudomonas fluorescens and neem cake }\end{array}$ \\
\hline $\begin{array}{l}\text { Accepted: } \\
\text { 08 August } 2018 \\
\text { Available Online: } \\
\text { 10 September } 2018\end{array}$ & $\begin{array}{l}(5 \mathrm{~kg} / \mathrm{palm} / \mathrm{year}) \text { and compared with root feeding of Hexaconazole @ } 3 \mathrm{ml} / 100 \mathrm{ml} \text { of } \\
\text { water/palm/quarter and micronutrient application @ } 1 \mathrm{~kg} / \mathrm{palm} / \mathrm{year} \text {. Among all the } \\
\text { treatments tested, soil application of talc based formulation of } 125 \mathrm{~g} \text { of Trichoderma reesei } \\
\text { and } 125 \mathrm{~g} \text { of Pseudomonas fluorescens }+5 \mathrm{~kg} \text { of Neem cake/ palm/year was found }\end{array}$ \\
\hline & $\begin{array}{l}\text { effective in reducing the disease index from } 28.44 \text { to } 4.23 \text { within a period of three (2014- } \\
\text { 2017) years and also found the increasing trend of the nut yield under field conditions. }\end{array}$ \\
\hline
\end{tabular}

\section{Introduction}

Coconut palm (Cocos nucifera, L.) is an important plantation crop of India and often described as 'Kalpavriksha' because of the multifarious uses of every part of it in the commercial sector. Coconut is grown in almost 94 countries in the world of which $90 \%$ of the production comes from Asian and Pacific countries. Andhra Pradesh occupies fourth position in coconut growing area and production (1.15 lakh ha; 1378 million nuts) after Kerala, Karnataka and Tamil Nadu with a productivity of 11957 nuts/ ha (2016-17).

In Andhra Pradesh, East Godavari $(50,490$ ha), West Godavari (21, 818 ha), Srikakulam $(14,753 \mathrm{ha})$ and Visakhapatnam (7300 ha) districts occupy major area in forefront in coconut cultivation. (www.cdb.nic.in). 
Coconut palms are normally affected by various insect pests and diseases resulting into reduction in yields. Among the various fungal diseases affecting coconut palm, basal stem rot (BSR) or wilt or root rot caused by Ganoderma spp. viz., $G$. lucidum, $G$. boninense, $G$. applanatum etc., is the most destructive. Ganoderma spp. has a wide host range attacking a variety of palms and several forest, avenue and fruit trees. According to Naidu et al., (1986), hosts belonging to 19 families, 36 genera and 48 species have been reported to be affected by Ganoderma spp. Coconut palms in the age group of 10-30 years are easily attacked by the pathogen.

Ganoderma is a soil-borne pathogen and it survives well in the soil for a long time. The formation of chlamydospores during adverse conditions helps survival of pathogen and chlamydospores become more resistant to environmental factors than basidiospores and could be responsible for dissemination of the disease. Irrigation water and rain water help in the spread of the fungus from one field to another.

Though, several researchers (Bhaskaran et al., 1994 and Srinivasulu et al., 2001) have reported different practices for the management of the disease, not much work has been done relating to the aspects of integrated disease management practices against Ganoderma under field conditions with bioagents. Keeping in view the minimal use of fungicides, the present investigation was taken up to develop an ecofriendly integrated disease management package against the basal stem rot disease by exploring the efficacy of native biocontrol agents under field conditions.

\section{Materials and Methods}

Studies on management of basal stem rot by using effective bioagents under field conditions was initiated with the new treatments in the selected garden at $P$. Gannavaram village of East Godavari District (variety: East coast tall) of Andhra Pradesh under All India Co-ordinated Research Project on Palms at Horticultural Research Station, Ambajipeta centre which is situated at $16.61308^{\circ} \mathrm{N}$ latitude and $81.89399^{\circ} \mathrm{E}$ longitudes and at an altitude of $14 \mathrm{~m}$ above mean sea level. There is a growing demand for biologically based soil borne pathogen management practices.

The experiment was carried out with 12 treatments (including control) as scheduled below from September 2014 to march 2017 for standardization of dosage, frequency and method of application of Trichoderma reesei, Pseudomonas fluorescens along with neem cake $(5 \mathrm{~kg} / \mathrm{palm} /$ year $)$, root feeding with Hexaconazole@ @3ml/100ml of water/palm/quarter and micronutrient application @ $1 \mathrm{~kg} / \mathrm{palm} / \mathrm{yr}$. Pre and post treatment data was recorded from the treated palms at regular intervals by recording the linear spread of the Ganoderma disease in coconut palms and also nut yield. The data was analyzed statistically as per the procedure given by Gomez and Gomez (1984).

Trees showing Ganoderma symptoms were randomly selected and each tree was considered as a replication, likewise five replications were maintained for each treatment

\section{Results and Discussion}

Earlier results revealed the native Trichoderma spp viz., T. viride, T. harzianum and $T$. hamatum were found to inhibit basal stem rot pathogens viz., Ganoderma applanatum and G. lucidum to an extent of 63 to $84 \%$ under in vitro conditions (Srinivasulu et al., 2002). Studies further proved that neem cake is a suitable substrate for mass 
multiplication of native Trichoderma spp (Srinivasulu et al., 2004). Further, neem cake has an advantage of inhibiting the growth of Ganoderma sp

Among the treatments evaluated, $\mathrm{T}_{9}$ Treatment (Soil application of talc based formulation of $125 \mathrm{~g}$ each of Trichoderma reesei and Pseudomonas fluorescens $+5 \mathrm{~kg}$ of neem cake/palm at yearly interval was found to be the best treatment by reducing the disease index from 28.44 to 6.20 during September 2014 to March 2016 (Table 1).

$\mathrm{T}_{9}$ treatment was on par with $\mathrm{T}_{3}$ treatment i.e soil application of talc based formulation of $125 \mathrm{~g}$ of Trichoderma reesei $+5 \mathrm{~kg}$ of neemcake/palm at yearly interval followed by $\mathrm{T}_{4}$ treatment (soil application of talc based formulation of $125 \mathrm{~g}$ of Pseudomonas fluorescens $+1.25 \mathrm{~kg}$ of neemcake/palm at quarterly interval) and showed a disease index reduction of 6.20, 6.36 respectively (Table 1).

Similar studies was carried out by Srinivasulu and Raghava Rao (2009), and reported that the application of Trichoderma spp. caused lysis of mycelium of Ganoderma lucidum. Furthermore, they have found that the application of $T$. harzianum/T. viride/T. hamatum pasted over bleeding patches and soil application of the bioagents @ $50 \mathrm{~g}$ in 5 $\mathrm{kg}$ neem cake has reduced the perimeter of the Ganoderma wilt patches on coconut trees.

Similarly, during 2016-17 season, $\mathrm{T}_{9}$ Treatment, soil application of talc based formulation of $125 \mathrm{~g}$ each of Trichoderma reesei and Pseudomonas fluorescens $+5 \mathrm{~kg}$ of neemcake/palm at yearly interval was found to be the best treatment among all the treatments and reduced the disease index from 5.12 to 4.23 (Table 2). $\mathrm{T}_{9}$ Treatment was followed by $\mathrm{T}_{3}$ treatment (soil application of talc based formulation of $125 \mathrm{~g}$ of Trichoderma reesei + $5 \mathrm{~kg}$ of neemcake/palm at yearly interval), $\mathrm{T}_{4}$
(Soil application of talc based formulation of $125 \mathrm{~g}$ of Pseudomonas fluorescens $+1.25 \mathrm{~kg}$ of neemcake/palm at quarterly interval) that showed 4.80, 5.36 reduction in disease index (Table 2). Studies conducted by earlier work indicated that rate of organic amendment can strongly influence the quality and subsequent crop performance in the field as well as rhizosphere bacterial communities (Allison et al., 2011).

In respect of nut yield, the pooled analysis from Sept. 2014 to March 2017 (Figure 1) clearly showed that increasing trend in bioagents applied treatments.

Among all the treatments evaluated, $\mathrm{T}_{9}$ treatment, soil application of talc based formulation of $125 \mathrm{~g}$ each of Trichoderma reesei and Pseudomonas fluorescens $+5 \mathrm{~kg}$ of neemcake/palm at yearly interval showed the highest nut yield (78 nuts/palm/year) followed by $\mathrm{T}_{3}$ treatment, (soil application of talc based formulation of 125 grams of Trichoderma reesei $+5 \mathrm{kgs}$ of neemcake/palm at yearly interval) which was recorded 73 nuts/palm/year and the lowest nut yield was recorded in $\mathrm{T}_{12}$ (Control) treatment (26 nuts/palm/year).

The pooled analysis data (Table 3) clearly showed that $\mathrm{T}_{9}$ treatment, soil application of talc based formulation of $125 \mathrm{~g}$ each of Trichoderma reesei and Pseudomonas fluorescens $+5 \mathrm{~kg}$ of neemcake/palm at yearly interval showed the lowest disease index of Ganoderma wilt $5.43 \pm 0.48$ and was followed by $\mathrm{T}_{3}$ treatment, (Soil application of talc based formulation of 125 grams of Trichoderma reesei $+5 \mathrm{kgs}$ of neemcake/palm at yearly interval), $\mathrm{T}_{4^{-}}$(Soil application of talc based formulation of 125 grams of Pseudomonas fluorescens $+1.25 \mathrm{Kg}$ of neemcake/palm at quarterly interval) that showed reduction in disease index of 5.61士 0.96 and $5.63 \pm 0.35$ respectively. 
Table.1 Disease index data of Ganoderma wilt in coconut at P. Gannavaram village September 2014 to March 2016

\begin{tabular}{|c|c|c|c|c|c|c|c|}
\hline $\begin{array}{l}\text { S. } \\
\text { No }\end{array}$ & Treatment & $\begin{array}{l}\text { Pre-treatment } \\
\text { September } \\
\text { (2014) }\end{array}$ & $\begin{array}{l}\text { March } \\
2015\end{array}$ & $\begin{array}{l}\text { June } \\
2015\end{array}$ & $\begin{array}{l}\text { September } \\
2015\end{array}$ & $\begin{array}{l}\text { December } \\
2015\end{array}$ & $\begin{array}{l}\text { March } \\
2016\end{array}$ \\
\hline $\mathrm{T}_{1}$ & $\begin{array}{l}\text { Soil application of talc based formulation of } 125 \mathrm{~g} \text { of Trichoderma reesei }+ \\
1.25 \mathrm{~kg} \text { of Neem cake/ palm at quarterly interval }\end{array}$ & 31.58 & 14.76 & 13.80 & 13.80 & 14.16 & 12.6 \\
\hline $\mathbf{T}_{2}$ & $\begin{array}{l}\text { Soil application of talc based formulation of } 125 \mathrm{~g} \text { of Trichoderma reesei }+ \\
2.5 \mathrm{~kg} \text { of Neem cake/ palm at six monthly interval }\end{array}$ & 33.30 & 15.98 & 15.92 & 14.12 & 14.24 & 14.12 \\
\hline $\mathbf{T}_{3}$ & $\begin{array}{l}\text { Soil application of talc based formulation of } 125 \mathrm{~g} \text { of Trichoderma reesei }+ \\
5 \mathrm{~kg} \text { of Neem cake/ palm/year }\end{array}$ & 35.78 & 8.48 & 7.40 & 6.30 & 6.72 & 6.20 \\
\hline $\mathbf{T}_{4}$ & $\begin{array}{l}\text { Soil application of talc based formulation of } 125 \mathrm{~g} \text { of Pseudomonas } \\
\text { fluorescens }+1.25 \mathrm{~kg} \text { of Neem cake/ palm at quarterly interval }\end{array}$ & 22.86 & 6.84 & 5.90 & 5.60 & 5.40 & 6.36 \\
\hline $\mathbf{T}_{5}$ & $\begin{array}{l}\text { Soil application of talc based formulation of } 125 \mathrm{~g} \text { of Pseudomonas } \\
\text { fluorescens }+2.5 \mathrm{~kg} \text { of Neem cake/ palm at six monthly interval }\end{array}$ & 26.12 & 26.72 & 27.32 & 25.52 & 24.68 & 24.2 \\
\hline $\mathrm{T}_{6}$ & $\begin{array}{l}\text { Soil application of talc based formulation of } 125 \mathrm{~g} \text { of Pseudomonas } \\
\text { fluorescens }+5 \mathrm{~kg} \text { of Neem cake/ palm/year }\end{array}$ & 25.16 & 29.72 & 31.04 & 29.00 & 26.40 & 31.88 \\
\hline $\mathbf{T}_{7}$ & $\begin{array}{l}\text { Soil application of talc based formulation of } 125 \mathrm{~g} \text { each of Trichoderma } \\
\text { reesei and Pseudomonas fluorescens }+1.25 \mathrm{~kg} \text { of Neem cake/ palm at } \\
\text { quarterly interval }\end{array}$ & 28.76 & 26.88 & 28.2 & 25.80 & 24.60 & 26.08 \\
\hline $\mathbf{T}_{8}$ & $\begin{array}{l}\text { Soil application of talc based formulation of } 125 \mathrm{~g} \text { each of Trichoderma } \\
\text { reesei and Pseudomonas fluorescens }+2.5 \mathrm{~kg} \text { of Neem cake/ palm at six } \\
\text { monthly interval }\end{array}$ & 23.91 & 16.16 & 15.56 & 14.24 & 16.40 & 16.40 \\
\hline $\mathbf{T}_{9}$ & $\begin{array}{l}\text { Soil application of talc based formulation of } 125 \mathrm{~g} \text { each of Trichoderma } \\
\text { reesei and Pseudomonas fluorescens }+5 \mathrm{~kg} \text { of Neem cake/ palm/year }\end{array}$ & 28.44 & 7.28 & 6.08 & 5.12 & 5.24 & 6.20 \\
\hline $\mathbf{T}_{10}$ & Root feeding of $1 \mathrm{ml}$ of Hexaconazole in $100 \mathrm{ml}$ water thrice in a year & 30.14 & 25.56 & 28.68 & 26.52 & 27.92 & 15.76 \\
\hline $\mathbf{T}_{11}$ & $\begin{array}{l}\text { Soil application of talc based formulation of } 125 \mathrm{~g} \text { each of Trichoderma } \\
\text { reesei and Pseudomonas fluorescens }+5 \mathrm{~kg} \text { of Neem cake/ palm/year+ } \\
\text { Root feeding with } 1 \mathrm{ml} \text { Hexaconazole } / 100 \mathrm{ml} \text { thrice in a year }+ \\
\text { Micronutrient application @ } 1 \mathrm{~kg} / \mathrm{palm} / \mathrm{year}\end{array}$ & 18.16 & 14.16 & 13.80 & 12.84 & 12.84 & 11.92 \\
\hline $\mathbf{T}_{12}$ & Control & 33.6 & 32.28 & 33.00 & 33.00 & 33.96 & 35.28 \\
\hline \multicolumn{3}{|c|}{ SEM+ } & 16.63 & 17.66 & 17.57 & 17.03 & 18.49 \\
\hline & $\mathrm{CD}(\mathrm{P}=\mathbf{0 . 0 5})$ & NS & 5.81 & 6.17 & 6.14 & 5.98 & 6.46 \\
\hline
\end{tabular}


Table.2 Disease index data of Ganoderma wilt in coconut at P. Gannavaram village April 2016 to March 2017

\begin{tabular}{|c|c|c|c|c|c|c|}
\hline $\begin{array}{l}\text { S. } \\
\text { No }\end{array}$ & Treatment & $\begin{array}{l}\text { Pre- } \\
\text { treatment } \\
\text { April (2016) }\end{array}$ & $\begin{array}{l}\text { June } \\
2016\end{array}$ & $\begin{array}{l}\text { Septembe } \\
\text { r } 2016\end{array}$ & $\begin{array}{l}\text { December } \\
2016\end{array}$ & $\begin{array}{l}\text { March } \\
2017\end{array}$ \\
\hline $\mathbf{T}_{1}$ & $\begin{array}{l}\text { Soil application of talc based formulation of } 125 \mathrm{~g} \text { of Trichoderma reesei }+1.25 \\
\mathrm{~kg} \text { of Neem cake/ palm at quarterly interval }\end{array}$ & 16.56 & 12.33 & 12.15 & 12.20 & 12.55 \\
\hline $\mathbf{T}_{2}$ & $\begin{array}{l}\text { Soil application of talc based formulation of } 125 \mathrm{~g} \text { of Trichoderma reesei }+2.5 \\
\mathrm{~kg} \text { of Neem cake/ palm at six monthly interval }\end{array}$ & 17.98 & 12.41 & 11.94 & 11.80 & 11.80 \\
\hline $\mathbf{T}_{3}$ & $\begin{array}{l}\text { Soil application of talc based formulation of } 125 \mathrm{~g} \text { of Trichoderma reesei }+5 \mathrm{~kg} \\
\text { of Neem cake/ palm/year }\end{array}$ & 9.52 & 5.20 & 4.20 & 3.20 & 2.80 \\
\hline $\mathbf{T}_{4}$ & $\begin{array}{l}\text { Soil application of talc based formulation of } 125 \mathrm{~g} \text { of Pseudomonas fluorescens } \\
+1.25 \mathrm{~kg} \text { of Neem cake/ palm at quarterly interval }\end{array}$ & 8.84 & 5.60 & 5.20 & 4.40 & 5.36 \\
\hline $\mathbf{T}_{5}$ & $\begin{array}{l}\text { Soil application of talc based formulation of } 125 \mathrm{~g} \text { of Pseudomonas fluorescens } \\
+2.5 \mathrm{~kg} \text { of Neem cake/ palm at six monthly interval }\end{array}$ & 36.52 & 21.75 & 21.46 & 21.46 & 22.13 \\
\hline$T_{6}$ & $\begin{array}{l}\text { Soil application of talc based formulation of } 125 \mathrm{~g} \text { of Pseudomonas fluorescens } \\
+5 \mathrm{~kg} \text { of Neem cake/ palm/year }\end{array}$ & 38.78 & 31.88 & 29.93 & 32.89 & 36.5 \\
\hline $\mathbf{T}_{7}$ & $\begin{array}{l}\text { Soil application of talc based formulation of } 125 \mathrm{~g} \text { each of Trichoderma reesei } \\
\text { and Pseudomonas fluorescens }+1.25 \mathrm{~kg} \text { of Neem cake/ palm at quarterly interval }\end{array}$ & 31.53 & 25.80 & 25.70 & 27.87 & 29.15 \\
\hline $\mathrm{T}_{8}$ & $\begin{array}{l}\text { Soil application of talc based formulation of } 125 \mathrm{~g} \text { each of Trichoderma reesei } \\
\text { and Pseudomonas fluorescens }+2.5 \mathrm{~kg} \text { of Neem cake/ palm at six monthly } \\
\text { interval }\end{array}$ & 14.40 & 15.16 & 14.19 & 13.91 & 12.60 \\
\hline $\mathrm{T}_{9}$ & $\begin{array}{l}\text { Soil application of talc based formulation of } 125 \mathrm{~g} \text { each of Trichoderma reesei } \\
\text { and Pseudomonas fluorescens }+5 \mathrm{~kg} \text { of Neem cake/ palm/year }\end{array}$ & 12.92 & 5.12 & 5.36 & 4.28 & 4.23 \\
\hline $\mathbf{T}_{10}$ & Root feeding of $1 \mathrm{ml}$ of Hexaconazole in $100 \mathrm{ml}$ water thrice in a year & 30.14 & 12.57 & 13.05 & 12.81 & 11.97 \\
\hline$T_{11}$ & $\begin{array}{l}\text { Soil application of talc based formulation of } 125 \mathrm{~g} \text { each of Trichoderma reesei } \\
\text { and Pseudomonas fluorescens }+5 \mathrm{~kg} \text { of Neem cake/ palm/year+ Root feeding } \\
\text { with } 1 \mathrm{ml} \text { Hexaconazole } / 100 \mathrm{ml} \text { thrice in a year }+ \text { Micronutrient application } \\
\text { @ } 1 \mathrm{~kg} / \mathrm{palm} / \text { year }\end{array}$ & 18.16 & 11.08 & 12.6 & 11.64 & 11.22 \\
\hline \multirow[t]{3}{*}{$\mathbf{T}_{12}$} & Control & 19.28 & 35.74 & 35.98 & 36.25 & 36.65 \\
\hline & SEM+ & & 16.38 & 20.1 & 18.9 & 20.06 \\
\hline & $\mathrm{CD}(\mathrm{P}=0.05)$ & NS & 5.75 & 7.05 & 6.63 & 7.04 \\
\hline
\end{tabular}


Table.3 Pooled analysis of disease index data of Ganoderma wilt in coconut at P. Gannavaram village over the years from 2014 to 2017

\begin{tabular}{|c|c|c|}
\hline $\begin{array}{l}\text { S. } \\
\text { No }\end{array}$ & Treatment & $\begin{array}{l}\text { Mean of three } \\
\text { years pooled data } \\
\text { of Ganoderma wilt } \\
\text { disease index }\end{array}$ \\
\hline $\mathbf{T}_{1}$ & $\begin{array}{l}\text { Soil application of talc based formulation of } 125 \mathrm{~g} \text { of Trichoderma reesei }+1.25 \mathrm{~kg} \text { of Neem cake/ palm at } \\
\text { quarterly interval }\end{array}$ & $13.15 \pm 0.49$ \\
\hline $\mathbf{T}_{2}$ & $\begin{array}{l}\text { Soil application of talc based formulation of } 125 \mathrm{~g} \text { of Trichoderma reesei }+2.5 \mathrm{~kg} \text { of Neem cake/ palm at six } \\
\text { monthly interval }\end{array}$ & $13.59 \pm 0.84$ \\
\hline $\mathbf{T}_{3}$ & Soil application of talc based formulation of $125 \mathrm{~g}$ of Trichoderma reesei $+5 \mathrm{~kg}$ of Neem cake/ palm/year & $5.61 \pm 0.96$ \\
\hline $\mathbf{T}_{4}$ & $\begin{array}{l}\text { Soil application of talc based formulation of } 125 \mathrm{~g} \text { of Pseudomonas fluorescens }+1.25 \mathrm{~kg} \text { of Neem cake/ palm } \\
\text { at quarterly interval }\end{array}$ & $5.63 \pm 0.35$ \\
\hline $\mathbf{T}_{5}$ & $\begin{array}{l}\text { Soil application of talc based formulation of } 125 \mathrm{~g} \text { of Pseudomonas fluorescens }+2.5 \mathrm{~kg} \text { of Neem cake/ palm at } \\
\text { six monthly interval }\end{array}$ & $23.92 \pm 1.15$ \\
\hline $\mathrm{T}_{6}$ & $\begin{array}{l}\text { Soil application of talc based formulation of } 125 \mathrm{~g} \text { of Pseudomonas fluorescens }+5 \mathrm{~kg} \text { of Neem cake/ } \\
\text { palm/year }\end{array}$ & $31.03 \pm 1.41$ \\
\hline $\mathbf{T}_{7}$ & $\begin{array}{l}\text { Soil application of talc based formulation of } 125 \mathrm{~g} \text { each of Trichoderma reesei and Pseudomonas fluorescens } \\
+1.25 \mathrm{~kg} \text { of Neem cake/ palm at quarterly interval }\end{array}$ & $26.68 \pm 0.73$ \\
\hline $\mathbf{T}_{8}$ & $\begin{array}{l}\text { Soil application of talc based formulation of } 125 \mathrm{~g} \text { each of Trichoderma reesei and Pseudomonas fluorescens } \\
+2.5 \mathrm{~kg} \text { of Neem cake/ palm at six monthly interval }\end{array}$ & $14.74 \pm 0.60$ \\
\hline $\mathbf{T}_{9}$ & $\begin{array}{l}\text { Soil application of talc based formulation of } 125 \mathrm{~g} \text { each of Trichoderma reesei and Pseudomonas fluorescens }+ \\
5 \mathrm{~kg} \text { of Neem cake/ palm/year }\end{array}$ & $5.43 \pm 0.48$ \\
\hline $\mathbf{T}_{10}$ & Root feeding of $1 \mathrm{ml}$ of Hexaconazole in $100 \mathrm{ml}$ water thrice in a year & $19.43 \pm 3.75$ \\
\hline $\mathbf{T}_{11}$ & $\begin{array}{l}\text { Soil application of talc based formulation of } 125 \mathrm{~g} \text { each of Trichoderma reesei and Pseudomonas fluorescens }+ \\
5 \mathrm{~kg} \text { of Neem cake/ palm/year+ Root feeding with } 1 \mathrm{ml} \text { Hexaconazole/100ml thrice in a year + Micronutrient } \\
\text { application@ } 1 \mathrm{~kg} / \mathrm{palm} / \mathrm{year}\end{array}$ & $12.46 \pm 0.54$ \\
\hline $\mathbf{T}_{12}$ & Control & $34.68 \pm 0.82$ \\
\hline
\end{tabular}


Fig.1 Nut yield data in Ganoderma wilt effected gardens in coconut at P. Gannavaram village over the years from 2014 to 2017

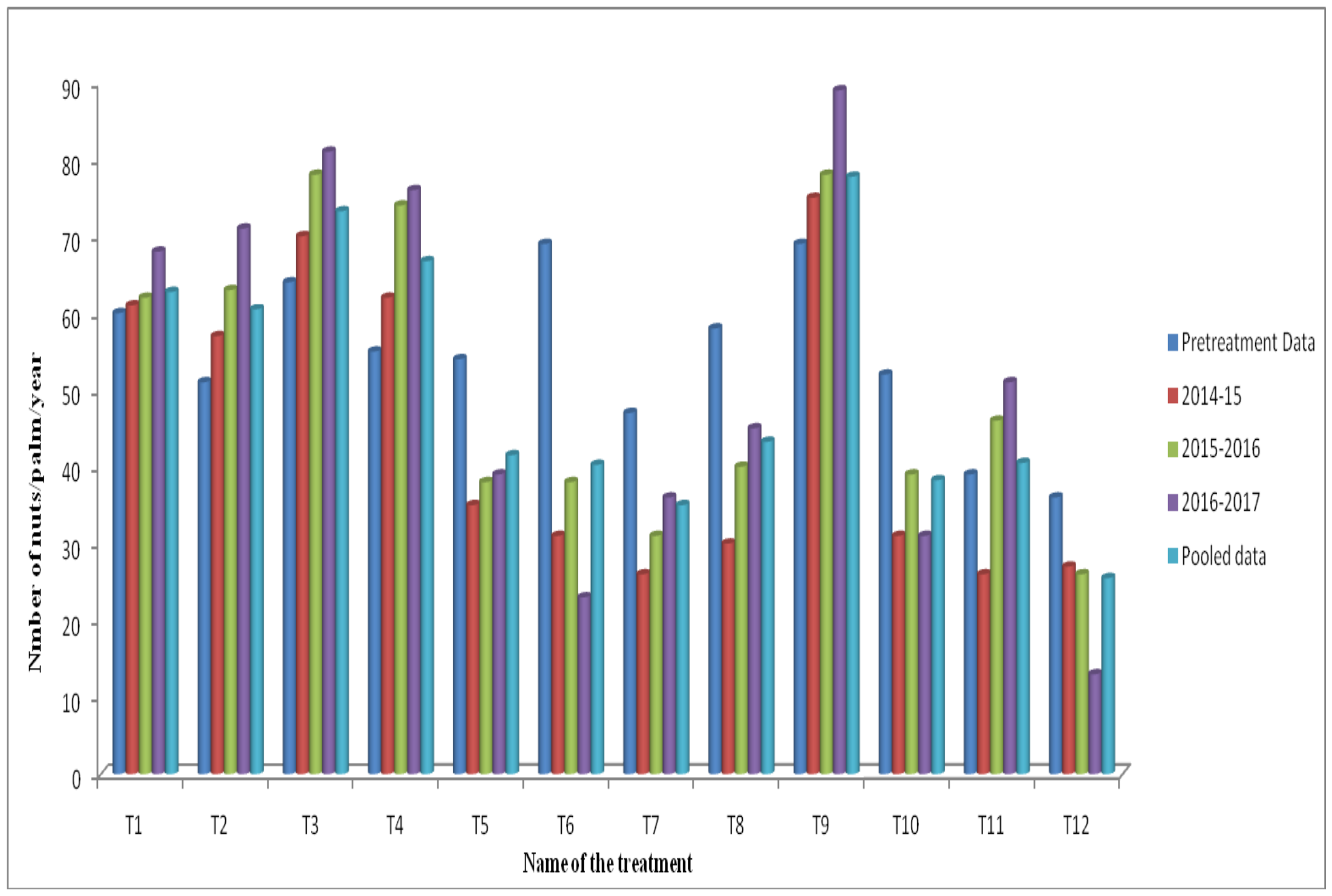




\section{Details of treatments imposed in integrated disease management against Ganoderma wilt disease}

\begin{tabular}{|c|c|}
\hline $\mathbf{T}_{1}$ & $\begin{array}{l}\text { il application of talc based formulation of } 125 \mathrm{~g} \text { of Trichoderma reesei }+1.25 \mathrm{~kg} \\
\text { Neem cake/ palm at quarterly interval }\end{array}$ \\
\hline $\mathbf{T}_{2}$ & $\begin{array}{l}\text { il application of talc based formulation of } 125 \mathrm{~g} \text { of Trichoderma reesei }+2.5 \mathrm{~kg} \text { of } \\
\text { eem cake/ palm at six monthly interval }\end{array}$ \\
\hline $\mathbf{T}_{3}$ & $\begin{array}{l}\text { il application of talc based formulation of } 125 \mathrm{~g} \text { of Trichoderma reesei }+5 \mathrm{~kg} \text { of } \\
\text { eem cake/ palm/year }\end{array}$ \\
\hline $\mathbf{T}_{4}$ & $\begin{array}{l}\text { il application of talc based formulation of } 125 \mathrm{~g} \text { of Pseudomonas fluorescens }+1.25 \\
\text { of Neem cake/ palm at quarterly interval }\end{array}$ \\
\hline $\mathbf{T}_{5}$ & $\begin{array}{l}\text { il application of talc based formulation of } 125 \mathrm{~g} \text { of Pseudomonas fluorescens }+2.5 \mathrm{~kg} \\
\text { Neem cake/ palm at six monthly interval }\end{array}$ \\
\hline$T_{6}$ & $\begin{array}{l}\text { il application of talc based formulation of } 125 \mathrm{~g} \text { of Pseudomonas fluorescens }+5 \mathrm{~kg} \\
\text { Neem cake/ palm/year }\end{array}$ \\
\hline $\mathbf{T}_{7}$ & $\begin{array}{l}\text { Soil application of talc based formulation of } 125 \mathrm{~g} \text { each of Trichoderma reesei and } \\
\text { Pseudomonas fluorescens }+1.25 \mathrm{~kg} \text { of Neem cake/ palm at quarterly interval }\end{array}$ \\
\hline $\mathbf{T}_{8}$ & $\begin{array}{l}\text { ch of Trichoderma reesei and } \\
\mathrm{t} \text { six monthly interval }\end{array}$ \\
\hline $\mathbf{T}_{9}$ & $\begin{array}{l}\text { Soil application of talc based formulation of } 125 \mathrm{~g} \text { each of Trichoderma reesei and } \\
\text { Pseudomonas fluorescens }+5 \mathrm{~kg} \text { of Neem cake/ palm/year }\end{array}$ \\
\hline $\mathbf{T}_{10}$ & Root feeding of $1 \mathrm{ml}$ of Hexaconazole in $100 \mathrm{ml}$ water thrice in a year \\
\hline $\mathbf{T}_{11}$ & $\begin{array}{l}\text { Soil application of talc based formulation of } 125 \mathrm{~g} \text { each of Trichoderma reesei and } \\
\text { Pseudomonas fluorescens }+5 \mathrm{~kg} \text { of Neem cake/ palm/year+ Root feeding with } 1 \mathrm{ml} \\
\text { Hexaconazole } / 100 \mathrm{ml} \text { thrice in a year + Micronutrient application @ } 1 \mathrm{~kg} / \mathrm{palm} / \mathrm{year}\end{array}$ \\
\hline & \\
\hline
\end{tabular}

Earlier results revealed that, application of two biocontrol agents together, a yeast (Pichia guilermondii) and a bacterium (Bacillus mycoides) resulted in better suppression of Botrytis cinerea, and also reduced the variability of disease control (Guetsky et al., 2001). Hence, application of more than one biocontrol agent is suggested as a reliable means of reducing the variability and increasing the reliability of biological control (Shtienberg and Elad, 2002).

$\mathrm{T}_{11}$ Treatment, Soil application of talc based formulation of $125 \mathrm{~g}$ each of Trichoderma reesei and Pseudomonas fluorescens $+5 \mathrm{~kg}$ of Neem cake/ palm/year+ root feeding with 1 $\mathrm{ml}$ Hexaconazole $/ 100 \mathrm{ml}$ thrice in a year + micronutrient application @ $1 \mathrm{~kg} / \mathrm{palm} /$ year showed disease index of $12.46 \pm 0.54$, this results revealed that hexaconazole effect on the biocontrol agents at field conditions. Earlier results revealed that systemic fungicide Hexaconazole was found incompatible with the biocontrol agents (Trichoderma harzianum) under in vitro conditions (Priti and Venkataravanappa, 2017). Bindu Madhavi et al., (2011) reported that Hexaconazole @ 5\% EC showed 94.4\% inhibition effect on Trichoderma viride under in vitro conditions.

Studies conducted by earlier workers indicated that the bacteria and fungi from the rhizosphere and belonging to a wide variety of genera have the potential to suppress diseases caused by a diversity of soil-borne 
plant pathogens. Some of these, especially Pseudomonas spp and Bacillus spp. significantly suppressed the disease and increases the yield of crops in field trials (Van Peer and Schippers, 1992). It is very difficult to eliminate or completely suppress Ganoderma since it is a soilborne fungus. Under these circumstances, environment friendly, safe and less expensive methods like biocontrol measures have great relevance in disease management. Therefore, it is necessary to go for a biocontrol approach by the use of effective native biological agents against the Basal stem rot disease (Ganoderma wilt) to manage the malady. In the present study, soil application of talc based formulation of $125 \mathrm{~g}$ each of Trichoderma reesei and Pseudomonas fluorescens $+5 \mathrm{~kg}$ of neemcake/palm at yearly interval was effective in managing the Basal stem rot disease (Ganoderma wilt) by stimulating plant defensive mechanisms with the use of effective native biocontrol agents in the soil.

\section{Acknowledgement}

This part of the work was done under All India Co-ordinated Research Project on Palms, ICAR.

\section{References}

Allison, L. H., Jacka Rangarajan, A., Culman, S. W., Sooksa-Nguand, T. and Thiese, J. E. (2011). Choice of organic amendments in tomato transplants has lasting effects on bacterial rhizosphere communities and crop performance in the field. Appl. Soil Ecol. 48, 94-101.

Bhaskaran, R., Rethinam, P. and Nambiar, K.K.N. (1994). Ganoderma wilt disease of coconut. Advances in Horticulture Vol. 10 - Plantation and Spice Crops Part - 2 (1994). pp 899-920.
Bindu Madhavi, G., Bhattiprolu, S.L. and Bali Reddy. V. (2011). Compatibility of biocontrol agent Trichoderma viride with various pesticides. J. Hortl. Sci. Vol. 6(1):71-73.

Gomez, K. A. and Gomez, A. A. (1984). Statistical Procedure for Agricultural Research. John Wiley and Sons, New York, 407 p.

Guetsky, R., Shtienberg, D., Elad, Y. and Dinoor, A. (2001). Combining biocontrol agents to reduce the variability of biological control. Phytopathology 91, 621-627.

http://www.coconutboard.gov.in/presentation/ statistics/statistics.aspx.

Naidu, G.V.B., Kumar, S.N.S. and Sannamarappa, M. (1966). Anabe roga, Ganoderma lucidum (Leys) Karst on arecanut palm: a review and further observations. Journal of Mysore Horticulture Society. 1(3): 14-20.

Priti sonavane and venkataravanappa. (2017). Compatibility studies of Trichoderma harzianum isolate with fungicides used against soil borne disease in Coorg mandarin-pepper-coffee plantations. International Journal of Current Microbiology and Applied Sciences, vol (6). pp. $346-354$.

Shtienberg, D. and Elad, Y. (2002). Is it possible to cope with variability of biological control? IOBC WPRS Bulletin 25, 1-4.

Srinivasulu, B. and Raghava Rao, D. V. (2009). Biocontrol of major diseases of coonut. In: P. Ponmurugan, and M. A. Deepa (eds): Role of Biocontrol Agents for Disease Management in Sustainable Agriculture. SCITECH (India) Pvt., Chennai pp. 352-368.

Srinivasulu, B., Aruna, K. and Rao D.V.R. (2001). Biocontrol of Ganoderma wilt of coconut palm. National Seminar on changing scenario in production system 
of Horticultural Crops, South Indian Hort. 49: 240-241.

Srinivasulu, B., Sabitha Doraisamy, Aruna, K., Rao, D.V.R. and Rabindran, R. (2002). Efficacy of biocontrol agent, chemicals and botanicals on Ganoderma $\mathrm{sp}$, the coconut basal stem rot pathogen. Journal of Plantation Crops, 30 (3): 5759.

Srinivaulu, B., Vijay Krishna Kumar, K., Aruna, K., Lakshmi, B.K.M. and Rao,
D.V.R. (2004). An ecofriendly technology to manage basal stem rot (Ganoderma wilt) disease of coconut. The Andhra Agricultural Journal, Vol 50 (Spl). pp. 264 - 267.

Van Peer R, and Schippers B. (1992). LPS of plant growth-promoting Pseudomonas sp. strain WCS417r induce resistance in carnation to Fusarium wilt. Netherland J. Plant Pathol. 98:129-39.

\section{How to cite this article:}

Neeraja, B., A. Snehalatharani, H.P. Maheswarappa, G. Ramanandam, N.B.V. Chalapathi Rao and Padma, E. 2018. Management of Basal Stem Rot (Ganoderma Wilt) in Coconut with Effective Bioagents under Field Condition. Int.J.Curr.Microbiol.App.Sci. 7(09): 1051-1060. doi: https://doi.org/10.20546/ijcmas.2018.709.125 